\title{
REORIENTASI ASAS ITIKAD BAIK/KEBENARAN SEBAGAI DASAR KEPEMILIKAN HAK ATAS TANAH
}

\author{
ORIGINAL REORIENTATION IS GOOD / TRUTH \\ AS THE BASIS OF LAND OWNERSHIP
}

\author{
Penulis \\ Supriyadi \\ Fakultas Hukum Universitas Semarang \\ supri_gombong@yahoo.com \\ Telp. 0811-276-284
}

\begin{abstract}
Abstrak
Perpindahan hak terhadap kepemilikan tanah terpancang pada aturan bahwa seseorang tak dapat mengalihkan sesuatu melebihi dari apa yang dimilikinya hal ini berhadapan dengan asas 'bona fides' (itikad baik) yang melindungi pembeli beritikad baik. Posisi hukumnya menempatkan dua belah pihak yang pada dasarnya tidak bersalah untuk saling berhadapan di pengadilan dan meminta untuk dimenangkan, akibat ulah pihak lain yang mungkin beritikad buruk. Pertanyaan mendasarnya, dalam hal ini pihak manakah yang seharusnya mendapatkan perlindungan hukum, apakah pemegang hak atas tanah atau pembeli yang mengaku beritikad baik? Alasan yang paling banyak digunakan adalah telah dilakukannya jual beli melalui notaris/PPAT Perlindungan terhadap pembeli beritikad baik adalah sebuah perkecualian, yaitu ketika pembeli tidak dapat menduga adanya suatu kekeliruan dalam peralihan hak dan kekeliruan itu terjadi akibat kesalahan pemilik sendiri (toedoenbeginsel). Jika kemudian timbul sengketa, maka harus dipertimbangkan apakah terjadinya peralihan yang tidak sah itu lebih disebabkan oleh kesalahan pembeli yang tidak mencermati asal usul tanah yang dibelinya, atau kesalahan pemilik asal yang tidak menjaga haknya dengan baik. UUPA dan PP No. 24/1997 tidak menjelaskan pengertian 'itikad baik'. Penegasan ini disimpulkan dari ketentuan KUHPerdata, literatur, dan putusan-putusan. Dalam hal ini, standar yang seharusnya digunakan bukan hanya tahu atau tidaknya pembeli berdasarkan pengakuannya sendiri (subyektif), namun juga apakah pembeli telah melakukan upaya untuk mencari tahu (obyektif), baik secara formil (dengan melakukan transaksi di depan PPAT, atau Kepala Desa jika transaksinya adalah tanah adat), maupun secara materiil
\end{abstract}

Kata kunci: itikad baik, ppat, jual beli

\begin{abstract}
Abstrack
The transfer of rights to land ownership is fixed on the rule that a person cannot transfer something more than what he has. This is faced with the principle of 'bona fides' (good faith) which protects buyers with good intentions. Its legal position places two basically innocent parties to face each other in court and ask to be won, due to the actions of other parties who may have bad intentions. The basic question is, in this case which party should get legal protection, are the holders of land rights or buyers who claim good
\end{abstract}


intentions? The most widely used reason is the sale and purchase through a notary / PPAT Protection of buyers with good intentions is an exception, that is when the buyer cannot predict the existence of an error in the transfer of rights and errors due to the owner's own fault (toedoenbeginsel). If a dispute arises, then it must be considered whether the illegitimate transition is caused more by the fault of the buyer who did not observe the origin of the land he bought, or the fault of the original owner who did not properly safeguard his rights. UUPA and PP No. 24/1997 does not explain the meaning of 'good faith'. This affirmation is concluded from the provisions of the Civil Code, literature, and decisions. In this case, the standard that should be used is not only whether or not the buyer is based on his own (subjective) recognition, but also whether the buyer has made an effort to find out (objectively), both formally (by conducting transactions before PPAT, or the Village Head if the transaction is customary land), and materially.

Keywords: good faith, ppat, buying and selling

\section{A. Latar Belakang Masalah.}

Pasal 33 ayat (3) Undang-Undang Dasar 1945 menyebutkan bahwa : “ Bumi , air, dan kekayaan alam yang terkandung didalamnya dikuasai oleh Negara dan dipergunakan untuk sebesar-besarnya kemakmuran rakyat “. Berbagai pengalaman historis membuktikan bahwa tanah sangat lengket dengan perilaku masyarakat bahkan tanah dapat menimbulkan berbagai masalah yang terjadi di masyarakat.

Tanah menempati peranan vital sebagai sumber daya hidup, maka dalam pengaturan dan penggunaannya harus memiliki norma-norma tertentu yang berkaitan dengan pertanahan ini, penduduk bertambah , pemikiran manusia berkembang, dan berkembang pulalah sistem , pola, struktur dan tata cara manusia menetukan sikapnya terhadap tanah. Seiring dengan perubahan dan perkembangan pola pikir, kepastian hukum dan kepastian hak atas tanah menempati urutan pertama yang selanjutnya akan menjadi dasar hukum terhadap kepemilikan atas objek tanah yang sedang atau yang akan dimilikinya.

Dengan adanya persoalan-persoalan, baik mengenai pertambahan penduduk maupun perkembangan ekonomi, maka kebutuhan terhadap tanah dalam kegiatan pembangunan akan meningkat. Berdasarkan kenyataan ini, tanah bagi penduduk Indonesia dewasa ini merupakan harta kekayaan yang paling tinggi nilainya dan juga merupakan sumber kehidupan, maka dari itu jengkal tanah dibela sampai titik darah penghabisan apabila hak tanahnya ada yang mengganggu. Untuk menjaga jangan sampai terjadi sengketa maka perlu diadakan pendaftaran tanah.

Pasal 19 UUPA yang pada ayat (1) nya menyatakan bahwa : “ Untuk menjamin kepastian hukum kepemilikan tanah pemerintah menyelenggarakan pendaftaran tanah di seluruh wilayah Republik Indonesia. Pendaftaran tanah mempunyai tahapan-tahapan 
sebagaimana termuat dalam ayat (2) nya dengan rincian bahwa pendaftaran tanah yang disebut pada ayat (1) tersebut meliputi :

a. Pengukuran, pemetaan, dan pembukuan tanah;

b. Pendaftaran hak-hak atas tanah dan peralihan hak-hak tersebut;

c. Pemberian surat tanda bukti hak yang berlaku sebagai alat bukti yang kuat.

Sebagai implementasi dari pasal 19 ayat (1) dan (2) ini maka dikeluarkanlah Peraturan Pemerintah di bidang Pendaftaran Tanah yaitu Peraturan Pemerintah Nomor 10 tahun 1961 mengenai Pendaftaran Tanah. Dan pendaftaran tanah dimaksud dijejaskan oleh Peraturan Pemerintah Nomor 10 Tahun 1961 pada pasal 2 ayat (1) nya yaitu harus dilakukan desa demi desa atau daerah-daerah yang setingkat dengan itu.

Dengan melihat konsepsi pasal 19 ayat (1 dan 2 ) UUPA serta pasal 2 ayat (1) PP Nomor 10 tahun 1961 tersebut di atas, maka kita dapat mengetahui bahwa pendaftaran tanah adalah perlu demi terciptanya kepastian hukum dan kepastian hak atas tanah. Dalam pelaksanaan pendaftaran ini, pemerintah akan melaksanakan secara sederhana dan mudah dimengerti dan secara berangsur-angsur. Konsepsi logis dari semua itu adalah ayat 2 c pasal 19 UUPA yaitu " akan diberikan tanda bukti hak/surat bukti hak, di mana surat-surat bukti hak tersebut akan berlaku sebagai alat pembuktian yang kuat. Inilah fungsi pokok sebenarnya dari pendaftaran tanah.

Jadi jelaslah sebenarnya bahwa tujuan pendaftaran tanah untuk memberikan kepastian hukum dan perlindungan hukum terhadap hak atas tanah. Pendaftaran Tanah adalah tugas dan beban pemerintah akan tetapi untuk mensukseskannya/ keberhasilannya sangat tergantung pada partisipasi aktif / peranan masyarakat terutama pemegang hak. Sistem pendaftaran tanah yang dianut oleh PP. No. 10 tahun 1961 adalah Sistem Negatif. Sistem ini disempurnakan atau dikembangkan oleh PP. No. 24 Tahun 1997 adalah asas negatif mengandung unsur positif, menghasilkan surat tanda bukti hak yang berlaku sebagai alat pembuktian yang kuat.

Jadi kalau dilihat dari tujuan pendaftaran tanah baik melalui Peraturan Pemerintah Nomor 10 tahun 1961 maupun Nomor 24 tahun 1997 maka status kepemilikan hak atas tanah bagi warga Negara Indonesia akan terjamin dan akan tercipta suatu kepastian baik mengenai, subjeknya, objeknya maupun hak yang melekat di atasnya termasuk dalam hal ini peralihan hak atas tanah. Hanya saja Kantor Pertanahan harus lebih aktif lagi mensosialisasikan kegiatan pendaftaran tanah baik mengenai tata cara, prosedur maupun biayanya serta pentingnya pendaftaran tanah ini bagi pemegang hak. Dan yang lebih penting lagi kantor 
Pertanahan harus senantiasa melakukan pemutakhiran data tanah agar tidak terjadi overlapping dalam pemberian haknya atau pendaftaran haknya yang dapat menimbulkan masalah hukum yaitu sengketa/perkara yang disebabkan oleh adalanya sertifikat ganda atau sertifikat palsu. Kantor Pertanahan haruslah senantiasa memutakhirkan datanya terutama buku tanah sebagai bank data .

Dalam realitas kehidupan kita ditengah-tengah masyarakat terdapat fakta bahwa masih banyak persoalan /sengketa tanah yang berawal dari belum terciptanya kepastian hukum atas sebidang tanah seperti masih adanya sengketa/perkara dibidang pertanahan sebagai akibat baik karena belum terdaftarnya hak atas tanah maupun setelah terdaftarnya hak atas tanah, dalam artian setelah tanah itu bersertifikat. Sehubungan dengan pendaftaran tanah, pertanyaan yang dapat timbul adalah siapakah yang sebenarnya yang ingin dilindungi oleh hukum dengan dilakukannya pendaftaran tanah ini.

\section{B. Pembahasan}

Prof. Dr. Maria S.W. Sumardjono, SH., MCL., MPA ${ }^{1}$ mengutarakan , bahwa Hukum menghendaki kepastian. Hukum Pertanahan Indonesia menginginkan kepastian siapa pemegang hak milik atau hak-hak lain atas sebidang tanah. Di dalam realitasnya, pemegang sertifikat atas tanah belum merasa aman akan kepastian haknya, bahkan sikap keragu-raguan yang seringkali muncul dengan banyaknya gugatan yang menuntut pembatalan sertifikat tanah melalui pengadilan.

Sedangkan menurut DR. Muchtar $\mathrm{Wahid}^{2}$, sertifikat tanah sebagai produk pendaftaran yang memenuhi aturan hukum normatif, belum menjamin kepastian hukum dari sudut pandang sosiologi hukum. Yang dimaksud oleh beliau kepastian hukum dari sudut pandang sosiologi hukum itu adalah realitas sosial yang terjadi di masyarakat. Dengan memperhatikan kemampuan pemerintah, maka pelaksanaan pendaftaran tanah dilakukan secara bertahap. Sebagai langkah awal dilakukan pengukuran desa-demi desa untuk memenuhi ketersediaan Peta Dasar Pendaftaran Tanah yang memuat titik-titik dasar tehnik dan unsur-unsur geografis serta batas fiksik bidang-bidang tanah. Pada wilayah yang belum dilakukan secara sistematik, peta dasar pendaftraan tanah sangat diperlukan untuk mengidentifikasi dan menentapkan letak tanah yang akan didaftarkan secara sporadik, dan selanjutnya menjadi dasar untuk pembuatan peta pendaftaran.

\footnotetext{
${ }^{1}$ Maria S.W. Sumardjono, 2001, Kebijakan Pertanahan Antara Regulasi dan Implementasi, Kompas Jakarta, hlm 37

${ }^{2}$ Muchtar Wahid, 2008, Memaknai Kepastian Hukum Hak Milik Atas Tanah, Republika Penerbit, Jakarta, hlm 9
} 
Sehubungan dengan pemberian kepastian hukum mengenai hak-hak atas tanah, baik mengenai subjek maupun objeknya, maka pemerintah mengharuskan dilakukan pengumuman mengenai hak -hak atas tanah, yang meliputi :

1. Pengumuman mengenai subjek yang menjadi pemegang hak yang dikenal dengan sebagai asas publisitas dengan maksud agar masyarakat luas dapat mengetahui tentang subjek dan objek atas satu bidang tanah . Adapun implementasi dari asas publisitas ini adalah dengan mengadakan pendaftaran tanah.

2. Penetapan mengenai letak, batas-batas, dan luas bidang - bidang tanah yang dipunyai seseorang atas sesuatu hak atas tanah, dikenal sebagai asas spesialitas daan implementasinya adalah dengan mengadakan Kadaster.

Dengan demikian ,maka seseorang yang hendak membeli suatu hak atas tanah tidak perlu melakukan penyelidikan sendiri, karena keterangan mengenai subyek dan objek atas suatu bidang tanah dapat diperoleh dengan mudah pada instansi pemerintah yang ditugaskan menyelenggarakan Pendaftaran Tanah.

Pelaksanaan pendaftaran tanah sebagaimana yang diatur oleh PP. No. 10 tahun 1961 belum berjalan efektif, hal ini selain sasaran utamanya/daerah yang diutamakan adalah daerah -daerah perkotaan, juga menyangkut tata cara, administrasi dan biaya yang harus ditanggung oleh masyarakat pemegang hak atas tanah sangatlah berat dirasakan oleh masayarakat pemegang hak atas tanah serta sosialisasi terhadap pelaksanaan PP itu sendiri belum maksimal. Dengan kondisi tersebut maka tujuan pendaftaran tanah belum tercapai.

Akselerasi dalam pembangunan nasional sangat memerlukan dukungan jaminan kepastian hukum di bidang pendaftaran tanah dan oleh karena PP. No. 10 Tahun 1961 dipandang tidak lagi sepenuhnya mendukung tercapainya hasil yang lebih nyata pada pembangunan nasional sehingga perlu dilakukan penyempurnaan. Dengan menimbang halhal tersebut, maka pemerintah memandang perlu membuat suatu aturan yang lengkap mengenai pendaftaran tanah yang dapat memenuhi kebutuhan masyarakat untuk adanya jaminan kepastian hukum dan akhirnya pada tanggal 8 Juli 1997 , Pemerintah telah mengeluarkan Peraturan Pemerintah Nomor 24 Tahun 1997. Dengan berlakunya PP. No. 24 Tahun 1997 tidak serta merta menghapuskan keberlakuan PP. No. 10 Tahun 1961, akan tetapi PP. No. 10 tahun 1961 tetap berlaku sepanjang tidak bertentangan dengan atau diubah atau diganti dengan Peraturan Pemerintah Nomor 24 tahun 1997. ( Pasal 64 ayat 1 PP. No. 24 Tahun 1997). 
Objek pendaftaran tanah ini bila dikaitkan dengan sistem pendaftaran tanah maka menggunakan sistem pendaftaran tanah bukan pendaftaran akta, karena sistem pendaftaran tanah ditandai/dibuktikan dengan adanya dokumen Buku Tanah sebagai dokumen yang memuat data yuridis dan data fisik yang dihimpun dan disajikan serta diterbitkannya sertifikat sebagai surat tanda bukti hak yang didaftar, sedangkan pendaftaran akta, yang didaftar bukan haknya, melainkan justru aktanya yang didaftar, yaitu dokumen-dokumen yang membuktikan diciptakannya hak yang bersangkutan dan dilakukannya perbuatan-perbuatan hokum mengenai hak tersebut kemudian.

Dengan adanya PP. Nomor 24 tahun 1997 ini, kelihatanya program atau kegiatan pendaftaran tanah mulai menggeliat, saat ini pendaftaran tanah sudah berjalan, namun perlu ditingkatkan terus dan mencari solusi yang efektif agar tujuan hakiki dari pendaftaran tanah terutama bagi tanah yang akan didaftar secara sistematis dan sporadik dapat tercapai.

Sistem pendaftaran tanah yang dianut oleh PP. No. 10 tahun 1961 adalah Sistem Negatif. Sistem ini disempurnakan atau dikembangkan oleh PP. No. 24 Tahun 1997 adalah asas negatif mengandung unsur positif, menghasilkan surat tanda bukti hak yang berlaku sebagai alat pembuktian yang kuat.

Pemerintah harus terus mencari cara dan sistem dalam rangka optimalisasi tujuan pendaftaran tanah terutama mengenai asas sederhana . aman dan terjangkau, sehingga golongan ekonomi lemahpun dapat termotifasi untuk mendaftarkan tanahnya terutama secara sistematis dan sporadik, walaupun saat ini sudah ada program Larasita yang lebih mendekatkan pada pelayanan dan bantuan biaya .

Jadi kalau dilihat dari tujuan pendaftaran tanah baik melalui Peraturan Pemerintah Nomor 10 tahun 1961 maupun Nomor 24 tahun 1997 maka status kepemilikan hak atas tanah bagi warga Negara Indonesia akan terjamin dan akan tercipta suatu kepastian baik mengenai, subjeknya, objeknya maupun hak yang melekat diatasnya termasuk dalam hal ini peralihan hak atas tanah. Hanya saja Kantor Pertanahan harus lebih aktif lagi mensosialisasikan kegiatan pendaftaran tanah baik mengenai tata cara, prosedur maupun biayanya serta pentingnya pendaftaran tanah ini bagi pemegang hak . Dan yang lebih penting lagi kantor Pertanahan harus senantiasa melakukan pemutakhiran data tanah agar tidak terjadi overlapping dalam pemberian haknya atau pendaftaran haknya yang dapat menimbulkan masalah hukum yaitu sengketa/perkara yang disebabkan oleh adalanya sertifikat ganda atau sertifikat palsu. Kantor Pertanahan haruslah senantiasa memutakhirkan datanya terutama buku tanah sebagai bank data . 
Sifat pembuktian sertifikat sebagai tanda bukti hak dimuat dalam pasal 32 PP no. 24 tahun 1997,yaitu :

1. Sertifikat merupakan surat tanda bukti hak yang berlaku sebagai alat pembuktian yang kuat mengenai data fisik dan data yuridis yang termuat di dalamnya,sepanjang data fisik dan data yuridis tersebut sesuai dengan data yang ada dalam surat ukur dan buku tanah yang bersangkutan.

2. Dalam atas hal suatu bidang tanah sudah diterbitkan sertifikat secara sah atas nama orang atau badan hukum yang memperoleh tanah tersebut dengan itikad baik dan secara nyata menguasainya, maka pihak lain yang merasa mempunyai hak atas tanah itu tidak dapat lagi menuntut pelaksanaan hak tersebut apabila dalam waktu 5 tahun sejak diterbitkannya sertifikat itu tidak mengajukan keberatan secara tertulis kepada pemegang sertifikat dan kepala kantor pertanahan yang bersangkutan ataupun tidak mengajukan gugatan kepengadilan mengenai penguasaan tanah atau penerbitan sertifikat. Ketentuan pasal ayat (1) Peraturan pemerintah no.24 tahun 1997 merupakan penjabaran dari ketentuan pasal 19 ayat (2) huruf c, pasal 23 ayat (2), Pasal 32 ayat (2), dan Pasal 38 ayat (2) UUPA, yang berisikan bahwa pendaftaran tanah menghasilkan surat tanda bukti yang berlakusebagai alat pembuktian yang kuat.

Berdasarkan ketentuan Pasal 32 ayat (1) Peraturan Pemerintah no.24 Tahun 1997, maka sistem publikasi pendaftaran tanah yang dianut adalah sistem publikasi negatif,yaitu sertifikat hanya merupakan surat tanda bukti yang mutlak. Hal ini berarti bahwa data fisik dan data yuridis yang tercantum dalam sertifikat mempunyai kekuatan hukum dan harus diterima hakim sebagai keterangan yang benar selama dan sepanjang tidak ada alat bukti lain yang membuktikan sebaliknya. Dengan demikian, pengadilanlah yang berwenang memutuskan alat bukti mana yang benar dan apabila terbukti sertifikat tersebut tidak benar, maka diadakan perubahan dan penbetulan sebagaiamana mestinya.

Ketentuan pasal 32 ayat (1) peraturan Pemerintah no. 24 tahun 1997 mempunyai kelemahan, yaitu Negara tidak menjamin kebenaran data fisik dan data yuridis yang disajikan dan tidak adanya jaminan bagi pemilik sertifikat dikarenakan sewaktu-sewaktu akan mendapatkan gugatan dari pihak lain yang merasa dirugikan atas diterbitkannya sertifikat.

Untuk menutupi kelemahan dalam ketentuan pasal 32 Ayat (1) Peraturan Pemerintah No.24 Tahun 1997 dan untuk memberikan perlindungan hukum kepada pemilik sertifikat dari gugatan dari pihak lain dan menjadikannya sertifikat sebagai tanda bukti yang bersifat 
mutlak. Maka dibuatlah ketentuan Pasal 32 ayat (2) Peraturan Pemerintah No. 24 tahun 1997, sertifikat sebagai surat tanda bukti hak yang bersifat mutlak apabila memenuhi unsur-unsur secara kumulatif,yaitu :

1. Sertifikat diterbitkan secara sah atas nama orang atau badan hukum 2. Tanah diperoleh dengan itikad baik.

2. Tanah dikuasai secara nyata.

3. Dalam waktu 5 tahun sejak diterbitkannya sertifikat itu tidak ada yang mengajukan keberatan secara tertulis kepada pemegang sertifikat dan kepala kantor pertanahan kabupaten/kota setempat ataupun tidak mengajukan gugatan ke pengadilan mengenai penguasaan tanah atau penerbitan sertifikat.

Secara lengkap bunyi ketentuan Pasal 32 ayat (2) Peraturan Pemerintah Nomor 24 Tahun 1997 menyatakan : Dalam hal atas suatu bidang tanah sudah diterbitkan sertipikat secara sah atas nama orang atau badan hukum yang memperoleh tanah tersebut dengan itikad baik dan secara nyata menguasainya, maka pihak lain yang merasa mempunyai hak atas tanah itu tidak dapat lagi menuntut pelaksanaan hak tersebut apabila dalam waktu 5 (lima) tahun sejak diterbitkannya sertipikat itutelah tidak mengajukan keberatan secara tertulis kepada pemegang sertipikat dan Kepala Kantor Pertanahan yang bersangkutan ataupun tidak mengajukan gugatan ke Pengadilan mengenai penguasaan tanah atau penerbitan sertipikat tersebut.

Menurut Dr. Irawan Soerodjo, SH., MSi, ${ }^{3}$ menyatakan bahwa ketentuan setelah 5 (lima) tahun sertipikat tanah tak bisa digugat, disatu sisi memberikan kepastian hukum dan perlindungan hukum tetapi disisi lain kebijakan tersebut juga riskandan tak memberikan perlindungan hukum kepada rakyat kecil yang sejauh ini belum sepenuhnya paham hukum. Pengumuman penerbitan sertipikat tanah di kantor kepala desa/kelurahan atau media massa tidak menjamin masyarakat dapat mengetahui atas adanya pengumuman sehubungan dengan penerbitan sertipikat. Hal ini dikarenakan masyarakat belum terbiasa membaca pengumuman di kelurahan atau media massa.

Elyana $^{4}$, menyatakan bahwa: Pembatasan 5 (lima) tahun saja hak untuk menggugat tanah yang telah bersertipikat harus disambut dengan rasa gembira karena akan memberikan kepastian hukum dan ketentraman pada orang yang telah memperoleh sertipikat tanah dengan itikad baik. Pengalaman menunjukkan bahwa sering terjadi sertipikat hak atas tanah yang telah berumur lebih dari 20 tahun pun (karena sertipikat tersebut telah diperpanjang sampai

\footnotetext{
${ }^{3}$ Irwan Soerodjo, 2002, Kepastian Hukum Hak Atas Tanah Di Indonesia, Arkola, Surabaya, hlm 187

${ }^{4}$ Ibid., hlm 186
} 
dengan 20 tahun lagi ) masih juga dipersoalkan dengan mengajukan gugatan. Bahkan baik di Pengadilan Negeri maupun ke Pengadilan Tata Usaha Negara dan pihak tergugat umumnya tidak berhasil dengan mengajukan eksepsi kedaluwarsaan baik akusatif maupun extingtip karena Hakim menganggap Hukum Tanah Nasional kita berpijak pada hukum adat yang tidak mengenal lembaga verjaring. Dengan adanya pembatasan 5 tahun dalam pasal 32 ayat 2 maka setiap Tergugat dalam kasus tanah yang sertipikatnya telah berumur 5 tahun dapat mengajukan eksepsi lewat waktu. Ketentuan pasal 32 ayat 2 ini dapat dipastikan akan banyak mengurangi kasus/sengketa tanah.

Lebih lanjut Dr. Irawan Soerodjo, SH., $\mathrm{MSi}^{5}$, menyatakan bahwa sedangkan Peraturan Pemerintah Nomor 24 Tahun 1997 menyebutkan setelah lewat jangka waktu 5 (lima) tahun setelah diterbitkan ; maka sertipikat tanah tak dapat digugat lagi, sehingga hal tersebut akan relatif lebih memberikan kepastian hukum dan perlindungan hukum.

Menurut kami, ketentuan ini pada prinsipnya menganut sistem publikasi positif, karena dengan adanya pembatasan waktu lewat dari 5 (lima) tahun tidak dapat digugat lagi oleh orang yang merasa berhak atas tanah termaksud. Dengan ketentuan bahwa proses permohonan dan pendaftaran maupun peralihan haknya senantiasa dilandasai oleh itikad baik atau kebenaran serta berpegang teguh pada asas Nemo Plus Yuris.

Dengan menerapkan kedua asas ini yaitu asas itikad baik/kebenaran dan asas Nemo Plus Yuris akan memberikan perlidungan hukum kepada pemegang sertifikat hak atas tanah, tentunya penerapan kedua asas ini harus dikuti pula dengan asas penguasaan fisik atas tanah termaksud,karena dengan menguasai secara fisik dan tanpa ada keberatan dari pihak lain , itu berarti masyarakat atau siapapun orangnya telah mengakui kepemilikan seseorang atas tanah yang dikuasainya itu. Dengan mebguasai terus menerus atas tanah termaksud berarti secara tidak langsung pemilik tanah itu menolak atau terhindar dari prinsip rechtsverwerking. Prinsip ini menyatakan bahwa pihak yang merasa mempunyai hak atas tanah harus mempertahankan haknya akan tetapi kalau pemilik tanah tidak memelihara atau mempertahankan haknya atas tanah termaksud berarti dia telah melepaskan haknya.

Di dalam penjelasan peraturan pemerintah No. 10 Tahun 1961 tentang pendaftaran tanah dinyatakan bahwa pembukuan suatu hak di dalam daftar buku tanah atas nama seseorang tidak mengakibatkan bahwa orang yang seharusanya berhak atas nama itu akan kehilangan haknya. Orang tersebut masih dapat menggugat hak dari yang terdaftar dalam buku tanah sebagai orang yang berhak. Jadi, cara pendaftaran hak yang diatur dalam

\footnotetext{
${ }^{5}$ Ibid., hlm 187
} 
peraturan pemerintah ini tidaklah positif, tetapi negative. Demikian penjelasan peraturan pemerintah No. 10 tahun 1961.

Pengertian sistem pendaftaran tanah yang positif mencakup ketentuan bahwa apa yang sudah terdaftar itu dijamin kebenaran data yang didaftarkannya dan untuk keperluan itu pemerintah meniliti kebenaran dan sahnya tiap warkah yang diajukan untuk didaftarkan sebelum hal itu dimaksukkan dama daftar-daftar.

Dalam sistem positif, Negara menjamin kebenaran data yang disajikan, sistem positif mengandung ketentuan-ketentuan yang merupakan perwujudan ungkapan "title by registration" (dengan pendaftaran diciptakan hak), pendaftaran menciptakan suatu "indefeasible title" (hak yang tidak dapat diganggu gugat) dan "the register is everything" (untuk memutuskan adanya suatu hak dan pemegang haknya cukup diliat buku tanahnya). Sekali didaftar pihak yang dapat membuktikan bahwa dialah pemegang hak yang sebenarnya kehilangan haknya untuk menuntut kembali tanah yang bersangkutan. Jika pendaftaran terjadi karena kesalahan pejabat pendaftaran dia hanya dapat menuntut pemberian ganti rugi atau kompensasi berupa uang. Untuk itu Negara menyediakan apa yang disebut sebagai suatu "assurance fund".

Ketentuan-ketentuan yang merupakan perwujudan-perwujudan ungkapan-ungkapan demikian tidak terdapat dalam UUPA. Dalam sistim publikasi negative juga dalam sistem negative, kita yang mengandung unsure positif, Negara tidak dapat menjamin kebenaran data yang disajikan. Penggunaannya adalah atas risiko pihak yang menggunakan sendiri. Di dalam asas Nemo plus yuris, perlindungan diberikan pada pemegang atas hak sebenarnya maka dengan asas ini selalu terbuka kemungkinan adanya gugatan kepada pemilik terdaftar dari orang yang merasa sebagai pemilik sebenarnya.

Terlepas dari kemungkinan kalah atau menangnya, tergugat yaitu pemegang hak terdaftar, maka hal ini berarti bahwa daftar umum yang diselenggarakan disuatu Negara dengan prinsip pemilik terdaftar tidak dilindungi hukum, tidak mempunyai kekuatan bukti. Ini berarti bahwa terdaftarnya seseorang di dalam daftar umum sebagai pemegang hak belum membuktikan orang itu seebagai pemegang hak yang sah menurut hukum. Jadi pemerintah tidak menjamin kebenaran dari sisi daftar-daftar umum yang diadakan dalam pendaftaran hak dan tidak pula dinyatakan dalam Undang-Undang.

Sebagai contoh lihat UUPA Pasal 23, 32 dan 38 yang isinya menyatakan pula dalam peralihan hak-hak (Hak milik, HGU, dan HGB) harus didaftar dan pendaftaran dimaksud merupakan alat pembuktian yang kuat mengenai sahnya peralihan hak tersebut. Kuat tidak 
berarti mutlak, namun lebih dari yang lemah sehingga pendaftaran berarti lebih menguatkan pembuktian pemilikan, akan tetapi tidak mutlak yang berarti pemilik terdaftar tidak dilindungi hukum dan bisa digugat sebagai mana dimaksud didalam penjelasan PP Nomor 10 Tahun 1961.

Hal pokok yang penting diluar perlindungan masalah hukum dan kekuatan bukti dari daftar-daftar umum ialah masalah artihukum dari suatu pendaftaran hak ataupun pendaftaran peralihan hak atas tanah.

Pasal 1 angka (20) Sertipikat adalah surat tanda bukti hak sebagaimana dimaksud dalam pasal 19 ayat 2 huruf (c) UUPA. Untuk hak atas tanah, hak pengelolaan, tanah wakaf, hak milik atas satuan rumah susun dan hak tanggungan yang masing-masing sudah dibukukan dalam buku tanah yang bersangkutan. Pasal 4 menyatakan :

1. Untuk memberikan kepastian dan perlindungan hukum sebagaimana dimaksud dalam pasal 3 huruf a kepda pemegang hak yang bersangkutan diberikan Sertifikat Atas Tanah

2. Untuk melaksanakan informasi sebagaimana dimaksud dalam pasal 3 huruf $b$ data fisik, data yuridis dari bidang tanah dan satuan rumah susun yang sudah terdaftar terbuka untuk umum

3. Untuk mencapai tertib administrasi sebagaimana dimaksud dalma pasal 3 huruf c, setiap bidang tanah dan satuan rumah susun termasuk peralihan, pembebanan dan hapusnya hak atas bidang tanah atas satuan rumah susun wajib didaftar

Dalam pendaftaran tanah dikenal dua macam sistem publiaksi, yaitu :

a. Sistem publiaksi positif yaitu apa yang terkandung dalam buku tanah dan suratsurat tanda bukti hak yang dikeluarkan merupakan alat pembuktian yang mutlak. Artinya pihak ketiga bertindak atas bukti-bukti tersebut diatas, mendapatkan perlindungan yang mutlak, biarpun dikemudian hari ternyata keterangan yang tercantum didalamnya tidak benar. Bagi mereka yang dirugiakn akan mendapat kompensasi ganti rugi. Dlam sistem publikasi positif, orang yang mendaftar sebagai pemegang hak atas tanah tidak dapat diganggu gugat lagi haknya. Dalam sistem ini, Negara sebagai pendaftar menjamin bahwa pendaftaran yang sudah dilakukan adalah benar.

Cirri-ciri sistem publikasi positif dalam pendaftaran tanah adalah :

1. Sistem pendaftaran tanah menggunakan sistem pendaftaran hak (registration of titles) 
2. Sertifikat yang diterbitkan sebagai tanda bukti hak bersifat mutlak, yaitu data fisik dan data yuridis yang tercantum dalamsertifikat tidak dapat diganggu gugat dan memberikan kepercayaan yang mutlak pada buku tanah

3. Negara sebagai pendaftar menjamin bahwa data fisik dan data yuridis dalam pendafataran tanah adalah benar.

4. Pihak ketiga yang memperoleh tanah dengan itikad baik mendapatkan perlindungan hukum yang mutlak.

5. Pihak lain yang dirugikan atas diterbitkannya sertifikat mendapatkan kompensasi dalam bentuk yang lain

6. Dalam pelaksanaan pendaftraan tanah membutuhkan waktu yang lama, petugas pendaftaran tanah melaksanakan tugasnya dengan sangat teliti, dan biaya yang relative lebih besar.

Boedi Harsono ${ }^{6}$ mengemukakan, dalam sistem positif, pendaftaran tanah menagnut sikap bahwa apa yang sudah terdaftar itu dijamin mencerminkan keadaan yang sebenarnya, baik tentang subyek hak maupun obyek haknya. Pemerintah menjamin kebenaran data yang telah terdaftar dan untuk keperluan tersebut pemerintah telah meneliti kebenaran dan sahnya tiap berkas yang diajukan untuk didaftarkan sebelum dimasukan kedalam daftar-daftar tanah. Dengan demikian subyekhak yang terdaftar sebagai pemegang hak atas tanah merupakan pemegang hak yang sah menurut hukum dan tidak bisa diganggu gugat dengan dasar atau alasan apapun juga. Orang yang namannya terdaftar sebagai pemegang hak dalam register, memperoleh apa yang disebut suatu indefeasible title (hak yang tidak dapat diganggu gugat). Dengan selesainya dilakukan pendaftaran atas nama penerima hak ,maka orang lain yang sebenarnya berhak menjadi kehilangan haknya. Ia tidak dapat menuntut pembatalan perbuatan hukum yang memindahkan hak yang bersangkutan kepada pembeli. Dalam keadaan tertentu ia hanya bisa menuntut ganti kerugian kepada Negara. Untuk menghadapi tuntutan ganti kerugian tersebut, Negara menyediakan suatu dana khusus.

b. Sistem publikasi negatif, sertifikat yang dikeluarkan merupakan tanda bukti hak atas tanah yang kuat, artinya semua keterangan yang terdapat dalam sertifikat mempunyaik kekuatan hukum dan harus diterima sebagai keterangan yang benar oleh hakim, selama tidak dibuktikan sebaliknya alat pembuktian yang lain.

Lebih lanjut Boedi Harsono mengatakan bahwa pendaftaran tanah yang menggunakan sistem publikasi negatif, Negara sebagai pendaftar tidak menjamin bahwa

\footnotetext{
${ }^{6}$ Boedi Harsono, 2003, Hukum Agraria Indonesia, (Edisi Revisi), Penerbit Djambatan, Jakarta, hlm 81-82
} 
orang yang terdaftar sebagai pemegang hak benar-benar orang yang berhak karena menurut sistem ini bukan pendaftaran tetapi sahnya perbuatan hukum yang dilakukan yang menentukan berpindahnya hak kepada pembeli. Pendaftaran tidak membikan orang yang memperoleh hak dari pihak yang tidak berhak menjadi pemegang hak yang baru

Dalam sistem publikasi negatif, jaminan perlindungan hukum yang diberikan pada pihak ketiga tidak bersifat mutlak seperti pada sistem positif. Piahk ketiga masih selalu berhati-hati dan tidak mutlak percaya pada apa yang tercantum dalam buku pendaftaran tanah atau surat tanda bukti hak yang dikeluarkannya.

Dalam sistem publikasi negatif berlaku asas nemo plus juris, artinya orang tidak dapat menyerahkan atau memindahkan hak melebihi apa yang dia sendiri dia punyai. Seseorang yang tidak berhak atas bidang tanah tertentu dengan sendidirnya tidak dapat melakukan suatu perbuatan hukum mendaftarkan tanah tersebut, apalagi mengalihkannya pada pihak lain. Asas nemo plus juris ini dalam rangka memberikan perlindungan hukum kepada pemilik tanah yang sebenarnya, yang tanahnya disertifikatkan pada orang lain

Ciri-ciri sistem publikasi negatif dalam pendaftaran tanah yaitu :

1. Sistem pendaftaran tanah menggunakan sistem pendaftaran akta ( registration of deed)

2. Sertifikat yang diterbitkan sebagai tanda bukti hak bersifat kuat, yaitu data fisik dan data yuridis yang tercantum dalam sertifikat dianggap benar sepanjang tidak dibuktikan sebaliknya oleh alat bukti yang lain. Sertifikat bukan sebagai satu satunya tanda bukti hak

3. Negara sebagai pendaftar tidak menjamin bahwa data fisik dan data yuridis dalam pendaftaran tanah adalah benar

4. Dalam sistem publikasi ini menggunakan lembaga kedaluwarsa

5. Pihak lain yang dirugikan atas diterbitkannya sertifikat dapat mengajukan keberatan kepada penyelenggara pendaftaran tanah untuk membatalkan sertifikat ataupun gugatan ke pengadilan untuk meminta agar sertifikat dinyatakan tidak sah

6. Petugas pendaftaran bersifat pasif, yaitu hanya menerima apa yang dinyatakan oleh pihak yang meminta pendaftaran tanah.

Apabila ditelaah dan dianalisis cara kerja sistem publikasi negatif ini, maka kami menyimpulkan bahwa dengan sistem ini pada dasarnya tidak dapat menciptakan kepastian hukum apalagi memberikan perlindungan hukum, karena masih ada kemungkinan pihak lain 
mengganggu kepemilikan pihak yang telah memegang sertifikat hak atas tanah sebagai bukti bahwa dia telah mematuhi perintah hukum dan atau aturan perundang-undangan, apalagi Negara kita hanya mengenal sistem hukum positif ., tidak ada sistem hukum negatif.

Muchtar Wahid menyatakan bahwa sistem negatif murni dapat menimbulkan ketidakpastian hukum. Kelemahan yang mendasar mengenai sistem negatif adalah pendaftaran tanah tidak menciptakan hak yang tidak dapat diganggu gugat. Yang menentukan sah atau tidaknya suatu hak serta pemilikannya adalah sahnya perbuatan hukum yang dilakukan, bukan pendaftarannya. Oleh karena itu, biarpun sudah didaftar dalam buku tanah dan diterbitkan sertifikat masih selalu dihadapi kemungkinan pemegang hak yang terdaftar kehilangan hak tanah yang dikuasainya karena digugat oleh pihak yang berhak sebenarnya ${ }^{7}$.

Kami sependapat dengan pendapat DR. Muchtar Wahid dan Boedi Harsono, memang seharusnyalah kelemahan dari sistem negatif ini ditutupi dan pendaftaran tanah kita kedepannya haruslah memilih sistem positif, agar tercipta kepastian hukum yang dapat melindungi kepentingan para pemegang sertifikat hak atas tanah.., tentunya pemohon hak yang berdasarkan dan atau dilandasi oleh itikad baik (kebenaran baik formil maupun materil) dan Nemo Plus Juris. Dan kedua asas ini dimiliki oleh manusia sebagai mahkluk Allah SWT., dan adalah sangat wajar untuk di realisasikan dan diwujudkan dalam tingkah laku dan tindak tanduk kehidupan kita sehari-hari.

\section{Kesimpulan}

Tujuan pendaftaran tanah adalah untuk memberikan kepastian hukum dan perlindungan hukum kepada pemegang hak atas tanah. Sertifikat hak atas tanah adalah sebagai bukti hak yang merupakan perwujudan dari proses pendaftaran tanah yang dapat memberikan kepastian hukum dan perlindungan hukum bagi pemegangnya.

Sistem pendaftaran tanah di Indonesia menganut sistem publikasi negatif yang bertendensi positif. Sistem ini pada dasarnya kurang memberikan kepastian hukum apalagi perlindungan hukum baik kepada pemegang sertifikat, maupun pihak ketiga yang memperoleh hak atas tanah. Untuk dapat lebih memberikan kepastian hukum dan perlindungan hukum sebaiknya UUPA kita atau hukum tanah kita menganut sistem publikasi positif.

Berdasarkan hal tersebut yang dilindungi dengan diadakannya pendaftaran tanah yaitu pemegang sertifikat hak atas tanah, karena dengan dilakukannya pendaftaran tanah berarti akan tercipta kepastian hukum, kepastian hak serta tertib administrasi pertanahan sehingga

\footnotetext{
${ }^{7}$ Muchtar Wahid, 2008, Memaknai Kepastian Hukum Hak Milik Atas Tanah, Republika Penerbit, Jakarta, hlm $75-76$
} 
semua pihak terlidungi dengan baik, baik pemegang sertifikat, pemegang hak atas tanah , pihak ketiga yang memperoleh hak atas tanah maupun pemerintah sebagai penyelenggara Negara.

\section{DAFTAR PUSTAKA}

Boedi Harsono, 2003, Hukum Agraria Indonesia, (Edisi Revisi), Penerbit Djambatan, Jakarta.

Irwan Soerodjo, 2002, Kepastian Hukum Hak Atas Tanah Di Indonesia, Arkola, Surabaya.

Maria S.W. Sumardjono, 2001, Kebijakan Pertanahan Antara Regulasi dan Implementasi, Kompas Jakarta.

Muchtar Wahid, 2008, Memaknai Kepastian Hukum Hak Milik Atas Tanah, Republika Penerbit, Jakarta. 